\title{
Effects of experimental reduction of light availability on the seagrass Amphibolis griffithii
}

\author{
Paul Mackey, Catherine J. Collier, Paul S. Lavery* \\ Centre for Ecosystem Management, Edith Cowan University, 100 Joondalup Drive, Joondalup, Western Australia 6027, \\ Australia
}

\begin{abstract}
The response of the meadow-forming seagrass Amphibolis griffithii (Black) den Hartog to light reduction was examined over a 3 mo period and a subsequent 1 mo recovery period. Morphological and physiological variables were measured in meadows subjected to an average reduction in photosynthetic photon flux density (PPFD) of $88 \%$ relative to unshaded controls. Leaf biomass, leaf cluster density and the number of leaves per cluster all declined in shaded plots, and after 3 mo were about 30,50 and $60 \%$ of the controls, respectively. Leaf extension was one-third that of the control plots. Epiphyte biomass in shaded plots was $44 \%$ of the controls after 6 wk of shading and $18 \%$ after 3 mo of shading. Leaf chlorophyll concentration was affected by shading, but only in the upper canopy: shaded leaves had 55\% more chlorophyll than control leaves. Shading reduced the carbohydrate stored in the rhizomes of shaded plants: sugars declined rapidly and continuously and, after $3 \mathrm{mo}$, were $<20 \%$ of the control values; a decline in starch concentrations lagged behind that of sugars. All variables showed a significant shift towards the values in control plots $42 \mathrm{~d}$ after removal of shading, indicating a capacity for recovery, though in many cases these variables remained significantly lower than those in the controls. A. griffithii and its epiphytes respond rapidly to severe, shortterm reductions in light availability, but responses at the scale of shoots and whole meadows also allow the plants to respond rapidly to improved light conditions.
\end{abstract}

KEY WORDS: Light · Environmental impact · Seagrass $\cdot$ Epiphytes $\cdot$ Amphibolis griffithii $\cdot$ Australia

\section{INTRODUCTION}

Reduced availability of light has been repeatedly implicated in the decline of seagrass meadows worldwide (Bulthius 1983, Longstaff \& Dennison 1999). Among the major causes of this reduced light availability are eutrophication, sedimentation and dredging activities (Walker \& McComb 1992, Duarte 2002). Much of the research into the responses of seagrasses to reduced light availability has attempted to identify the minimum light requirements of seagrasses or early indicators of possible seagrass loss. Most research has focussed on a few species, particularly those of Posidonia (Gordon et al. 1994, Ruiz \& Romero 2003) and smaller, fast-growing tropical species (Longstaff \& Dennison 1999). These species have shown both morphological and physiological responses to reduced light availability. Typical responses include the loss of above-ground biomass and shifts in leaf morphology and pigment concentrations (Czerny \& Dunton 1995, Lee \& Dunton 1997) that may allow the plant to maintain a neutral or positive carbon budget (Touchette \& Burkholder 2000) by reducing the draw on storage reserves (Peralta et al. 2002) or decreasing selfshading in the canopy (Carruthers \& Walker 1997).

Amphibolis griffithii is endemic to southern and western Australia, where it is one of the dominant meadow-forming species. Compared with those seagrasses with strap-like leaves, such as Posidonia, little research has been directed at the genus Amphibolis. This is perplexing given that its structure (Ducker et al. 1977), morphology (Marba \& Walker 1999) and physiology (Paling \& McComb 1994) differ considerably from the strap-like species. A. griffithii plants invest a higher proportion of their biomass in above-ground tissue, contrasting with other 'larger' seagrasses. They also 
have an unusual above-ground morphology: the plant is large (30 to $100 \mathrm{~cm}$ ), with a relatively thin horizontal rhizome that branches vertically into 'stems' (Ducker et al. 1977). A number of leaf clusters containing 3 to 5 leaves are situated along terminating ends of the vertical, branching, lignified stems (Marba \& Walker 1999). This produces a complex habitat structure and more persistent substrate for epiphytes compared to seagrasses with strap-like leaves. Amphibolis species have relatively thin rhizomes and, potentially, a lower capacity to store carbohydrate reserves. Amphibolis is placed towards the centre of the seagrass functionalform model (Walker et al. 1999), reflecting these differences. This all suggests that transposing models and knowledge of environmental impact to the morphologically unique genus Amphibolis from other species, such as Posidonia, may be inappropriate.

In 2003 dredging operations in a port north of the study site produced a sediment plume of approximately $140 \mathrm{~km}^{2}$, with reductions in photosynthetic photon flux density (PPFD) of $>90 \%$ relative to ambient conditions over an area of at least $10 \mathrm{~s}$ of $\mathrm{km}^{2}$ (Geraldton Port Authority unpubl. data). This led to mortality among Amphibolis spp. over $10 \mathrm{~s}$ of $\mathrm{km}^{2}$ and to severe reductions in biomass in a larger surrounding area. These sorts of dredging operations are increasingly a threat to seagrass ecosystems, and understanding the capacity of seagrasses to withstand prolonged and high-intensity reductions to PPFD is a first step in managing impacts.

The aim of the present study was to determine the morphological and physiological responses of Amphibolis griffithii to severe reductions in light availability, comparable in magnitude and length to those produced by more severe dredging activities, and then to examine recovery when light reduction ceased. We also aimed to identify potential indicators of sub-lethal light stress from these responses. We hypothesised that Amphibolis would have a low capacity to withstand severe shading due to its thin rhizome structure and presumed low capacity to store carbohydrate reserves. It was also hypothesised that there would be a severe loss of above-ground material to reduce the respiratory load and the draw on storage reserves. These hypotheses were consistent with the generic functional-form model of seagrasses (Walker et al. 1999), which suggests that Amphibolis spp. would be more responsive to perturbation than larger species such as Posidonia spp.

\section{MATERIALS AND METHODS}

Experimental design and analysis. A field experiment was conducted at Jurien Bay on the central Western Australian coast in an extensive ( $>6$ ha) Amphibo- lis griffithii meadow, in 4.0 to $4.5 \mathrm{~m}$ water depth, 200 to $300 \mathrm{~m} \mathrm{NE}$ of Boullanger Island $\left(30^{\circ} 18^{\prime} 34^{\prime \prime} \mathrm{S}\right.$, $\left.115^{\circ} 00^{\prime} 26^{\prime \prime} \mathrm{E}\right)$. The experiment took place in late summer, the period when Amphibolis griffithii plants have their highest levels of carbohydrate storage reserves (Carruthers \& Walker 1997) and, theoretically, the greatest capacity to withstand reductions in light availability by drawing on those reserves to compensate for reduced carbon fixation. In this sense, any response should represent the minimum that an intense lightreduction event is likely to produce.

Replicate treatment and control plots were randomly located within a $50 \times 50 \mathrm{~m}$ study area. Replicate treatment plots $(\mathrm{n}=4)$ of Amphibolis griffithii meadow were subjected to shading (covered by $80 \%$ PPFDattenuating shade cloth) for $106 \mathrm{~d}$, the intensity and duration reflecting those observed in areas adjacent to harbour dredging programmes in the region. Each experimental unit measured $4.5 \times 3.0 \mathrm{~m}$ and was covered by a shade screen constructed of 8 metal pickets driven into the sediment at the corners and mid-points of the longest side, stainless steel wire running around the pickets and the shade cloth attached to the wire. Control plots were as above, but lacked the shade cloth. Attempts to establish procedural controls, with monofilament net suspended from the pickets, proved useless; they fouled rapidly with epiphytic algae, resulting in a 20 to $30 \%$ reduction in photosynthetically active radation (PAR) after a few days. Consequently, the procedural controls were abandoned as they would alter the incident PAR and confound the results. Previous attempts at maintaining procedural controls for shading have also appeared futile (Bulthius 1983, C. J. Collier unpubl. data).

The final workable area used for experimental sampling was approximately $4.5 \mathrm{~m}^{2}$ in the centre of the plots, the remainder being deemed unusable due to lateral intrusion of light. The total destructive sampling area throughout the duration of the study was calculated at $<9 \%$ of the total sampling area.

Morphological and physiological variables were sampled just prior to imposing the treatments and after 42, 66 and $106 \mathrm{~d}$. After $106 \mathrm{~d}$ the shade screens were removed from the treatment plots, and all plots were re-sampled after a further $42 \mathrm{~d}$ to test for any recovery. Differences within and between treatments over time were tested using repeated-measures ANOVA. Treatment and Time were considered fixed factors, since the levels were chosen to mimic those of typical dredging operations. Prior to conducting ANOVA, all data were tested for compliance with assumptions of homogeneity of variance and normality. Non-compliant data were transformed, as per Fowler \& Cohen (1990).

Photosynthetic photon flux density. PPFD $(\mu \mathrm{mol}$ photon $\mathrm{m}^{-2} \mathrm{~s}^{-1}$ ) was measured at the top of the seagrass 
canopy in a randomly chosen control and treatment plot using 'Odyssey Dataflow' submersible incident light sensors, with an automated wiper unit to keep the sensor clean (Carruthers et al. 2001). To determine attenuation through the water column, shade screens and seagrass canopy, PPFD was measured at the water surface, just above and below the shade screens and at the top and bottom of the seagrass canopy during and after the shading phase of the experiment using a Li-Cor LI1000 quantum photometer.

Above- and below-ground biomass and morphological variables. One permanent $0.04 \mathrm{~m}^{2}$ quadrat was established in the centre of each experimental plot at the commencement of the study. Stem density, percentage cover and maximum and average canopy heights $(\mathrm{cm})$ were measured non-destructively in the permanent quadrats, as per Duarte \& Kirkman (2001). Above-ground biomass was measured destructively in a $20 \times 20 \mathrm{~cm}$ quadrat placed randomly in the sampling area of each plot. All stems in the quadrat were cut off at sediment level and placed immediately in a bag. Later, the above-ground material was separated into leaf, stem and epiphyte components for every $10 \mathrm{~cm}$ layer of the canopy (as per Carruthers \& Walker 1997) to determine leaf, stem and epiphyte biomass, and leaf and leaf cluster density, as per Duarte \& Kirkman (2001). These components were counted and dried at $60^{\circ} \mathrm{C}$ for $48 \mathrm{~h}$. To minimise destructive sampling of the plot area, a single core sample $\left(0.01 \mathrm{~m}^{2}, 20 \mathrm{~cm}\right.$ deep $)$ was collected from inside the above-ground biomass quadrat to quantify below-ground biomass. The sample was sieved through a $1 \mathrm{~mm}$ mesh and separated into root, rhizome and detritus before drying as described above. The disturbance sites were marked to ensure the same or immediate adjacent areas were not re-sampled.

Physiological and growth variables. Leaf extension was measured over the 2 wk period preceding sampling events, as per Short \& Duarte (2001). A standard leather punch was used to insert a hole at the base of the newest (youngest) leaf. All leaf clusters were marked on approximately 12 stems in each plot. After approximately $14 \mathrm{~d}$, the leaf clusters were harvested and returned to the laboratory. New growth was removed and scraped free of epiphytes, and leaf length was measured, then dried $\left(60^{\circ} \mathrm{C}\right.$ for $\left.48 \mathrm{~h}\right)$ and weighed.

Leaves and rhizomes were collected for pigment and carbohydrate analysis immediately adjacent to the quadrat destructively harvested for biomass sampling. Leaf clusters were collected from the top and bottom of the canopy, wrapped in aluminium foil while underwater and then stored in darkness at $-18^{\circ} \mathrm{C}$ prior to analysis. A $30 \mathrm{~mm}$ section from the youngest mature leaf, both at the top and bottom of the canopy, was consistently chosen for analysis to avoid senescent and/or necrotic tissue and to ensure fully developed pigment characteristics (Hemminga \& Duarte 2000). In a darkened room, the leaf material was finely chopped with a razor blade, ground in a cold mortar and pestle and then combined in a centrifuge tube with $10 \mathrm{ml}$ of chilled $90 \%$ acetone. Chlorophyll extraction and spectrophotometric measurement followed the methods of Granger \& Lizumi (2001) and Longstaff \& Dennison (1999) to determine the total chlorophyll (chl) $a+b$ concentration and chl $a / b$ ratios.

Total soluble sugars and starch analyses were performed on oven-dried $\left(60^{\circ} \mathrm{C}\right.$ for $\left.48 \mathrm{~h}\right)$, ground leaves (upper and lower canopy) and rhizomes. The samples were twice extracted in hot $80 \%$ ethanol. Spectrophotometric concentrations were determined using the 'phenol-sulphuric acid' method (Dubois \& Gilles 1956). Starch content of the remaining material was analysed according to Quarmby \& Allen (1989), following gelatinisation at $100^{\circ} \mathrm{C}$ for $15 \mathrm{~min}$ and solubilisation in $70 \%$ perchloric acid.

\section{RESULTS}

\section{Photosynthetic photon flux density}

Over the 5 wk measurement period, the average $( \pm$ SE) daily maximum PPFD at the top of the seagrass canopy in control and shaded plots was $147 \pm 6$ and $18 \pm 2 \mu \mathrm{mol} \mathrm{m} \mathrm{m}^{-2} \mathrm{~s}^{-1}$, respectively, with an average reduction in shaded plots of $88 \pm 1 \%$ relative to control plots. At the end of the shading period, there were significant differences in the canopy attenuation of PPFD in shaded and control plots (light attenuation coefficient $=2.38$ and $0.59 \mathrm{~m}^{-1}$, respectively). At midday on the last day of shading, the top of the seagrass canopy received $378 \mu \mathrm{mol} \mathrm{m}{ }^{-2} \mathrm{~s}^{-1}$ in the control plots and $12 \mu \mathrm{mol} \mathrm{m}^{-2} \mathrm{~s}^{-1}$ in the shaded plots. The lower canopy received $47 \mu \mathrm{mol} \mathrm{m}{ }^{-2} \mathrm{~s}^{-1}$ in the control plots and $4 \mu \mathrm{mol}$ $\mathrm{m}^{-2} \mathrm{~s}^{-1}$ in the shaded plots, equating to 12 and $33 \%$ of the PPFD reaching the top of the canopy, respectively. Once shade screens were removed, the differences in canopy attenuation coefficients resulted in far greater penetration of PPFD through the previously shaded canopies, with $68 \pm 7 \mu \mathrm{mol} \mathrm{m}^{-2} \mathrm{~s}^{-1}$ reaching the bottom of the previously shaded plots and $10 \pm 1 \mu \mathrm{mol} \mathrm{m}{ }^{-2} \mathrm{~s}^{-1}$ reaching the bottom of the control plots.

\section{Morphological and physiological responses}

Above- and below-ground biomass and morphology

The total leaf biomass displayed declined significantly in shaded plots (Fig. 1A, Table 1) and, after 
$106 \mathrm{~d}$, was about one-third of the biomass in unshaded plots $\left(150 \pm 38\right.$ and $452 \pm 103 \mathrm{~g} \mathrm{~m}^{-2}$, respectively). Following removal of the shade screens, leaf biomass increased in the shaded plots and, after $42 \mathrm{~d}$, was similar to that in the controls.

The mean number of leaves per stem declined over time in the shaded plots (from about 25 to $15 \mathrm{stem}^{-1}$;
Fig. 1B, Table 1), but increased following removal of shading and, after $42 \mathrm{~d}$, was similar to that in the controls. Leaf loss was distributed over all leaf clusters, the number of leaves per cluster showing a similar response to leaves per stem (Fig. 1C, Table 1), but in this case the difference persisted after shading was removed. The density of clusters also declined sig-
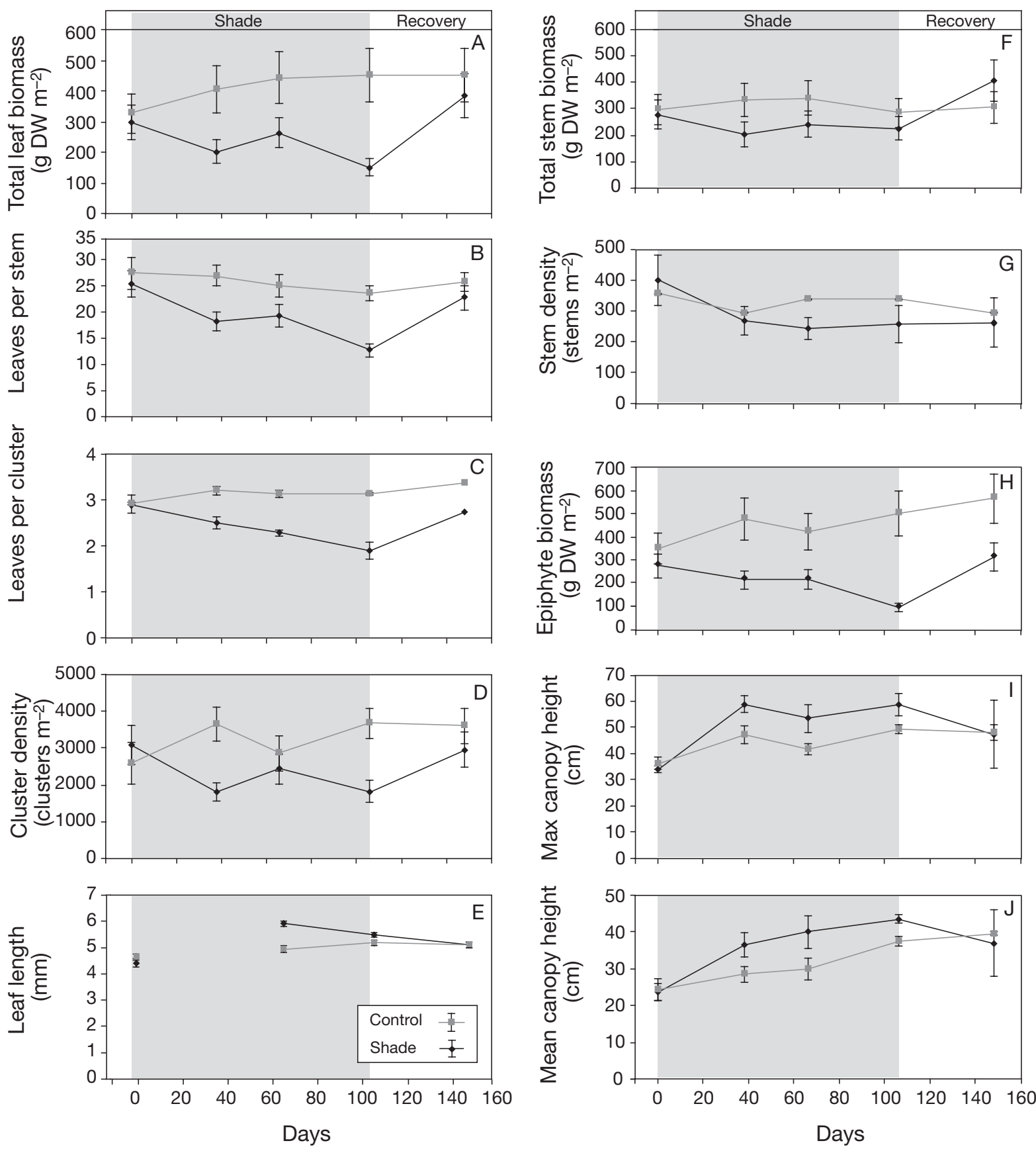

Fig. 1. Amphibolis griffithii. Above-ground shoot and meadow characteristics during shading and subsequent recovery periods in shaded and control plots: (A) leaf biomass (DW: dry weight), (B) leaves per stem, (C) leaves per cluster, (D) cluster density, (E) leaf length, (F) stem biomass, (G) stem density, (H) epiphytic algal biomass, (I) maximum canopy height and (J) mean canopy height. Data are means $( \pm \mathrm{SE}, \mathrm{n}=4)$ 
Table 1. Amphibolis griffithii. Summary of the 1-way repeated-measures ANOVA to assess the significance of shading and time effects on the selected meadow variables. In all cases the error $\mathrm{df}$ is 24 , except maximum canopy height ( $\mathrm{df}=6.9)$ and average canopy height ( $\mathrm{df}=9.6$ ), which failed the test for sphericity and were adjusted (Greenhouse-Geisser), and leaf extension and areal leaf extension

$(\mathrm{df}=18)$, which were measured on only 4 occasions. DW: dry weight; Trt: shading treatment; ${ }^{*} \mathrm{p}<0.001 ;{ }^{* *} \mathrm{p}<0.01 ;{ }^{* * *} \mathrm{p}<0.05$

\begin{tabular}{|c|c|c|c|c|c|c|c|c|c|c|c|}
\hline Factor & Variable & $\mathrm{df}$ & MS & $F$ & $\mathrm{p}$ & Factor & Variable & df & MS & $F$ & $\mathrm{p}$ \\
\hline Time & Leaf biomass & 4 & 31.7 & 2.0 & & Time & \% canopy cover & 4 & 2570 & 25.05 & ${ }^{* * *}$ \\
\hline Trt & $\left(\mathrm{g} \mathrm{DW} \mathrm{m} \mathrm{m}^{-2}\right)$ & 1 & 390.7 & 8.5 & $*$ & Trt & & 1 & 2088 & 2.44 & \\
\hline Time $\times$ Trt & & 4 & 38.8 & 2.4 & & Time $\times$ Trt & & 4 & 453.33 & 4.42 & $* *$ \\
\hline Time & Leaves stem $^{-1}$ & 4 & 71.5 & 3.6 & $*$ & Time & Root biomass & 4 & 0.02 & 0.26 & \\
\hline Trt & & 1 & 429.4 & 13.6 & * & Trt & $\left(g \mathrm{DW} \mathrm{m} \mathrm{m}^{-2}\right)$ & 1 & 0.14 & 10.03 & $*$ \\
\hline Time $\times$ Trt & & 4 & 28.3 & 1.4 & & Time $\times$ Trt & & 4 & 0.06 & 0.73 & \\
\hline Time & Leaves cluster $^{-1}$ & 4 & 0.8 & 11.4 & $* *$ & Time & Rhizome biomass & 4 & 0.67 & 1.29 & \\
\hline Trt & & 1 & 4.8 & 34.6 & **** & Trt & $\left(\mathrm{g} D W \mathrm{~m}^{-2}\right)$ & 1 & 1.02 & 3.51 & \\
\hline Time $\times$ Trt & & 4 & 0.9 & 13.2 & $* *$ & Time $\times$ Trt & & 4 & 0.23 & 0.45 & \\
\hline Time & Cluster density & 4 & 500071 & 0.3 & & Time & Detrital biomass & 4 & 31.49 & 2.68 & \\
\hline Trt & $\left(\mathrm{m}^{-2}\right)$ & 1 & 7272299 & 10.2 & * & Trt & $\left(\mathrm{g} \mathrm{DW} \mathrm{m} \mathrm{m}^{-2}\right)$ & 1 & 15.27 & 0.46 & \\
\hline Time $\times$ Trt & & 4 & 2015992 & 1.4 & & Time $\times$ Trt & & 4 & 3.62 & 0.31 & \\
\hline Time & Leaf length & 4 & 0.04 & 7.2 & $* *$ & Time & Leaf sugar & 4 & 17350 & 3.32 & $*$ \\
\hline Trt & $(\mathrm{mm})$ & 1 & 0.01 & 1.0 & & Trt & & 1 & 15440 & 8.05 & $*$ \\
\hline Time $\times$ Trt & & 4 & 0.02 & 3.5 & * & Time $\times$ Trt & & 4 & 11165 & 2.14 & \\
\hline Time & Stem biomass & 4 & 17.6 & 1.3 & & Time & Leaf starch & 4 & 8086 & 1.44 & \\
\hline Trt & $\left(\mathrm{g} \mathrm{DW} \mathrm{m} \mathrm{m}^{-2}\right)$ & $\begin{array}{l}4 \\
1\end{array}$ & 14.1 & $\begin{array}{l}1.0 \\
0.8\end{array}$ & & Trt & & 1 & 464.2 & 0.17 & \\
\hline Time $\times$ Trt & & 4 & 20.1 & 1.5 & & Time $\times$ Trt & & 4 & 7041 & 1.25 & \\
\hline Time & Stem density & 4 & 0.2 & 1.6 & & Time & Rhizome sugar & 4 & 19.61 & 5.94 & $* *$ \\
\hline Trt & $\left(\mathrm{m}^{-2}\right)$ & 1 & 0.5 & 0.5 & & Trt & & 1 & 123.30 & 32.81 & $* * *$ \\
\hline Time $\times$ Trt & & 4 & 0.1 & 0.6 & & Time $\times$ Trt & & 4 & 13.65 & 4.14 & ${ }^{*}$ \\
\hline Time & Epiphyte biomass & 4 & 0.7 & 0.9 & & Time & Rhizome starch & 4 & 0.41 & 4.48 & $* *$ \\
\hline Trt & $\left(\mathrm{g} \mathrm{DW} \mathrm{m}^{-2}\right)$ & 1 & 20.1 & 6.8 & & Trt & & 1 & 1.40 & 15.72 & $* *$ \\
\hline Time $\times$ Trt & & 4 & 1.4 & 1.9 & & Time $\times$ Trt & & 4 & 0.20 & 2.23 & \\
\hline Time & Max. canopy height & $\mathrm{t} 1.152$ & 20.83 & 2.47 & & Time & $\mathrm{Chl} a / b$ & 4 & 0.51 & 16.44 & $* * *$ \\
\hline Trt & $(\mathrm{cm})$ & 1 & 0.05 & 0.51 & & Trt & (upper canopy) & 1 & 0.16 & 3.37 & \\
\hline Time $\times$ Trt & & 1.152 & 0.29 & 0.87 & & Time $\times$ Trt & & 4 & 0.06 & 1.77 & \\
\hline Time & Avg. canopy height & $\mathrm{t} 1.6$ & 817.61 & 6.18 & & Time & Chl $a / b$ & 4 & 0.17 & 6.26 & * \\
\hline Trt & $(\mathrm{cm})$ & 1 & 176.40 & 2.18 & & Trt & (bottom canopy) & 1 & 0.07 & 5.03 & \\
\hline Time $\times$ Trt & & 1.6 & 147.85 & 1.12 & & Time $\times$ Trt & & 4 & 0.01 & 0.25 & \\
\hline Time & Leaf extension & 3 & 0.07 & 14.82 & $* * *$ & Time & $\mathrm{Chl}$ & 4 & 34751696 & 17.75 & $* * *$ \\
\hline Trt & & 1 & 0.38 & 80.35 & *** & Trt & (upper canopy) & 1 & 41154751 & 13.95 & $*$ \\
\hline Time $\times$ Trt & & 3 & 0.05 & 10.56 & $* * *$ & Time $\times$ Trt & & 4 & 13774146 & 7.04 & $* * *$ \\
\hline Time & Areal leaf extension & n 3 & 1594842 & 5.80 & $*$ & Time & $\mathrm{Chl}$ & 4 & 12080766 & 3.58 & $*$ \\
\hline Trt & & 1 & 6802590 & 24.12 & $* *$ & Trt & (bottom canopy) & 1 & 655671 & 0.19 & \\
\hline Time $\times$ Trt & & 3 & 785877 & 2.86 & & Time $\times$ Trt & & 4 & 1611822 & 0.48 & \\
\hline
\end{tabular}

nificantly in the shaded treatments (Fig. 1D, Table 1), but increased after shading and, after $42 \mathrm{~d}$, was similar to that in the control plots. After $66 \mathrm{~d}$ of shading, leaves in shaded plots were longer $(5.9 \pm 0.1 \mathrm{~mm})$ than those in controls $(4.9 \pm 0.1 \mathrm{~mm})$, but not at the end of the shading period (Fig. 1E). The distributions of leaf biomass through the canopy changed during the shading period (Fig. 2A). Over time, shaded plots had lower leaf biomass; this was mostly due to reductions in the mid-canopy (up to $60 \mathrm{~cm}$ above the sediment surface).

Stem biomass and density, root biomass, rhizome biomass and detrital biomass remained relatively stable throughout the study, with little difference between treatments and control (Figs. 1F,G \& 3). Maximum and average canopy heights also remained relatively stable over time, with maxima of about 30 to $58 \mathrm{~cm}$ and average heights of 25 to $38 \mathrm{~cm}$ (Fig. 1I,J).
The distribution of stem biomass through the canopy displayed no significant effect due to shading (Fig. 2B).

\section{Epiphyte biomass}

After $42 \mathrm{~d}$ of shading, epiphyte biomass was less than half that in the control plots (Fig. 1H) and, at the end of the shading period, was $<20 \%$ of controls ( $92 \pm 82$ and $500 \pm 29 \mathrm{~g}$ dry weight $\mathrm{m}^{-2}$, respectively). When normalised to leaf biomass, epiphyte biomass declined in the shaded plots, from $0.98 \pm 0.19$ to $0.66 \pm 0.53 \mathrm{~g} \mathrm{~g}^{-1}$, but was unchanged in the controls $(1.04 \pm 0.20$ to $1.14 \pm$ $0.66 \mathrm{~g} \mathrm{~g}^{-1}$ ). The most dramatic differences in epiphyte biomass were in the mid-canopy levels (Fig. 2C). By the end of the recovery period, $42 \mathrm{~d}$ after shading had been removed, these differences were much reduced. 
Leaf extension

Leaf extension in control plots remained about $0.6 \mathrm{~mm} \mathrm{leaf}^{-1} \mathrm{~d}^{-1}$ over the experimental period, but in shaded plots decreased to approximately one-third of this after $106 \mathrm{~d}$ of shading (Fig. 4E, Table 1). The differences between control and shaded plots persisted $12 \mathrm{~d}$ post-shading, but were not significant $42 \mathrm{~d}$ postshading. Areal leaf extension $\left(\mathrm{mm} \mathrm{m}^{-2} \mathrm{~d}^{-1}\right)$ followed similar patterns to leaf extension rates (Fig. 4J, Table 1).


Fig. 2. Amphibolis griffithii. Distribution of (A) leaf, (B) stem and $(\mathrm{C})$ epiphytic algal biomass through the canopy of shaded and control meadows. Data are means $( \pm \mathrm{SE}, \mathrm{n}=4)$
Sugars and starch

In the rhizomes, sugar concentrations declined sharply in the shaded treatments (Fig. 4A). After $38 \mathrm{~d}$, sugar concentrations in shaded treatments were $60 \%$ of the controls and after $106 \mathrm{~d}$ were $19 \%$ of the controls. Following removal of shading, rhizome sugar concentrations increased, but were still significantly lower than those in the controls. Starch concentration in the rhizome declined with shading, but was not significantly lower than that in the control until Day 106, when the concentration had fallen to $50 \%$ of the control values; it showed only a minor increase $42 \mathrm{~d}$ after removal of shading (Fig. 4B).

In the leaves, the concentration of total soluble sugars was affected by shading, but not starch (Fig. 4F,G). After $38 \mathrm{~d}$, the mean sugar concentration in the shaded treatments was $47 \%$ that of the controls. For the remainder of the shading period, the concentration of sugars in the shaded leaves remained at about $100 \mathrm{mg} \mathrm{g}^{-1}$, while in the controls it fell, so that by the end of the shading period, and throughout the recovery period, there were no significant differences between the two. Concentrations of starch in the leaves at the start of the experiment were significantly higher in the treatment plots than in controls, making control versus impact comparisons difficult. In shaded treatments, the concentration declined over the duration of the shading treatment. From Day 38 onwards, values in the controls also declined, and, after 106 $\mathrm{d}$, there were no concentration differences between shaded and control plants. During the recovery period, neither the shaded nor control plants showed any significant change in leaf starch concentration.

\section{Chlorophyll}

Shading had a significant effect on the chlorophyll concentration of leaves, but only in the upper canopy (Fig. 4H, Table 1), where shaded leaves had higher concentrations than controls. After $106 \mathrm{~d}$ of shading, the mean chl $a+b$ concentration in shaded plants was $55 \%$ greater than that in controls. Once shading was removed, the chlorophyll concentration of the upper leaves in the shaded treatments fell and, after $42 \mathrm{~d}$, was similar to that in the controls. The ratio of $\mathrm{chl} a / b$ was not affected by shading (Fig. 4C,D).

\section{DISCUSSION}

\section{Responses to shading}

Functionally, the above-ground responses of Amphibolis griffithii are largely analogous to those of other large seagrasses with different (strap-like leaf) mor- 

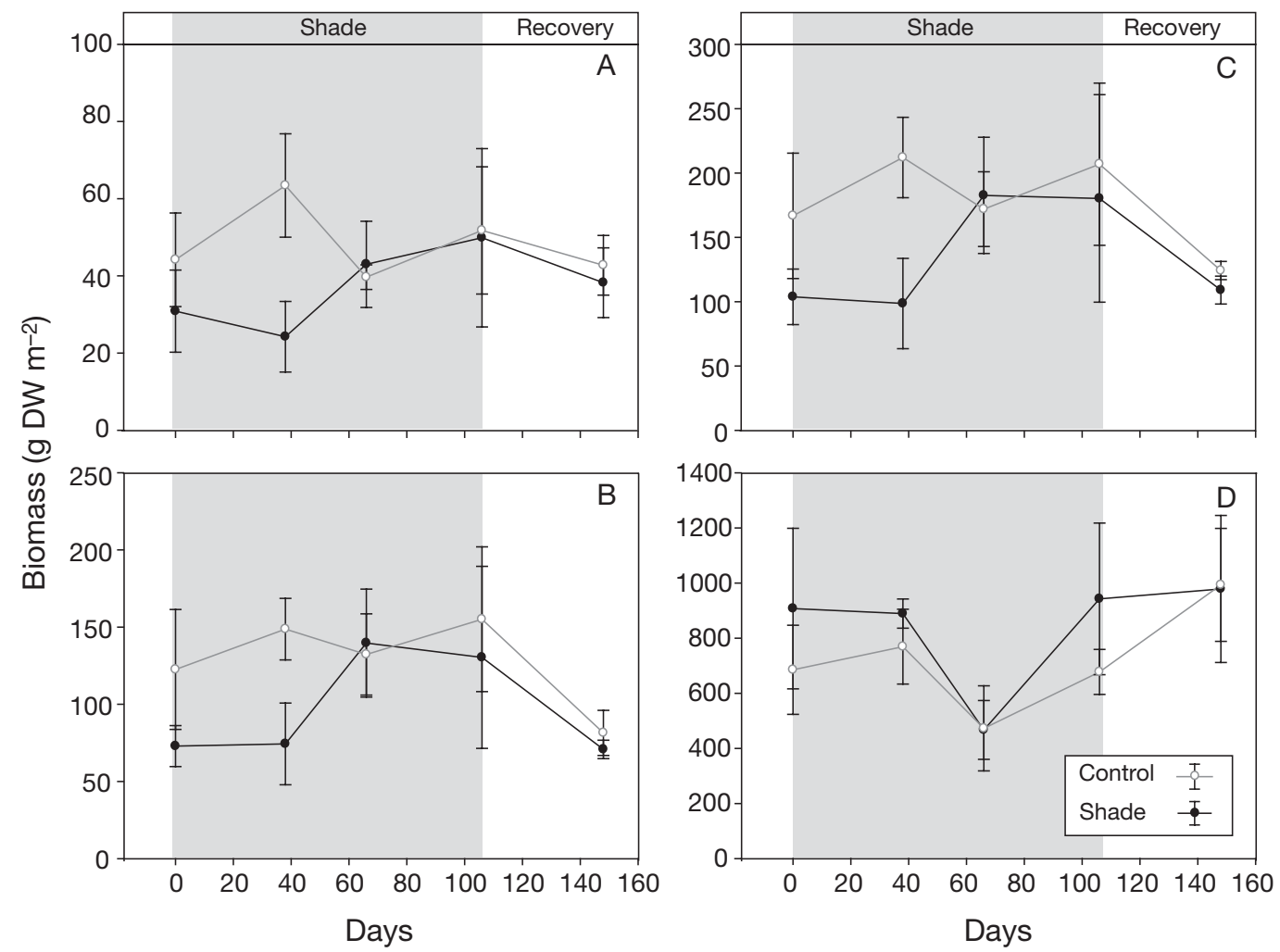

Fig. 3. Amphibolis griffithii. Below-ground biomass characteristics of meadows during shading and subsequent recovery periods in shaded and control plots: (A) total below-ground biomass (rhizome + root + detritus), (B) rhizome biomass, (C) root biomass and (D) detritus biomass. Data are means $( \pm \mathrm{SE}, \mathrm{n}=4)$

phologies. In a reduced-light climate both morphological forms of seagrass appear to gain energy efficiency by reducing the highest respiratory demanding components - shoots comprised leaves in the majority of seagrasses, and leaves and leaf clusters in the case of A. griffithii, but not the low-energy-demanding stems. Leaves can have respiratory loads up to 6 times that of below-ground material (Masini et al. 1995), and the above- to below-ground biomass ratio in the genus Amphibolis is approximately 6 (Paling \& McComb 2000). Therefore, the dramatic reduction in aboveground tissue that we noted would have the effect of reducing the total plant respiratory load.

The reduction in above-ground biomass at the individual stem and shoot level also thinned the seagrass canopy and reduced the degree of self-shading; they attenuated almost 2 orders of magnitude less light than control canopies. This response has been noted for other seagrasses and may assist in recovery of the remaining leaves once light conditions improve (Carruthers \& Walker 1997). In other species, there have been no reports of whether the loss of leaves is random or not. Interestingly, in this study, the loss of leaves was not random, occurring largely in the mid-canopy, the portion of the canopy most affected by self-shading, but not at the top of the canopy, where light levels are greatest. Thus, while the loss of leaves may simply be a progressive defoliation response, the non-random nature might also indicate an adaptive strategy to optimise the radiation use efficiency of the canopy (as noted by Carruthers \& Walker 1997).

Presumably, shedding of leaves was not sufficient to balance the plants' carbon budgets, since carbohydrate reserves in the rhizome were simultaneously depleted. In shaded plots, leaf sugars initially declined rapidly following reductions in PPFD, then stabilised. Rhizome sugar concentrations also declined following shading, possibly reflecting translocation to the leaves. The decline in rhizome starch concentrations lagged behind that of sugars, possibly reflecting a reallocation of rhizome sugars and, later, starch to the leaves, a reallocation of resources similar to that found in other seagrasses (e.g. Touchette \& Burkholder 2000, Peralta et al. 2005). It is unclear how much stored carbohydrate is lost with the shed leaves. No studies of carbon resorption have been undertaken for Amphibolis spp., but in other seagrasses nutrient resorption can account for up to 10 and $15 \%$ of the $\mathrm{N}$ and $\mathrm{P}$ requirements for new production (Stapel \& Hemminga 1997). Leaf longevity influences the retention time of nutrients in 
plant tissues (Escudero et al. 1992). Whether plants undergoing a leaf-shedding response to light reduction increase the rate of carbohydrate resorption is unclear, but is worthy of investigation.

The change in carbohydrate reserves observed in shaded plants was superimposed on a seasonal response. While the shaded plants showed an initial decline in leaf sugar concentrations relative to the con-
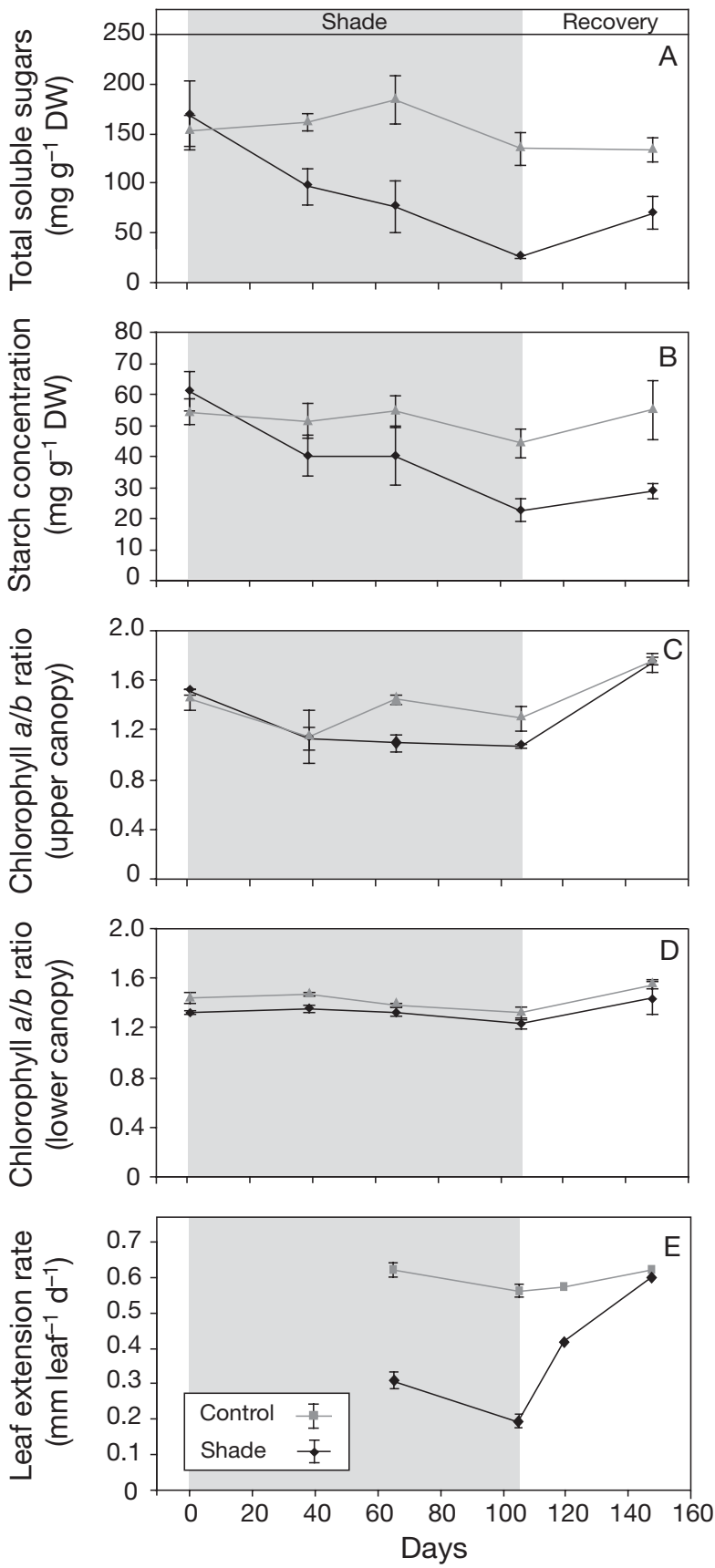

trols, by the end of the shading period both the treatment and control plants had similar sugar levels in the leaves. We suggest that this is due to the control plants entering the normal winter period of reduced ambient light and drawing on their carbohydrate reserves. However, unlike the shaded plants, the unshaded plants maintained significantly higher rhizome storage reserves.
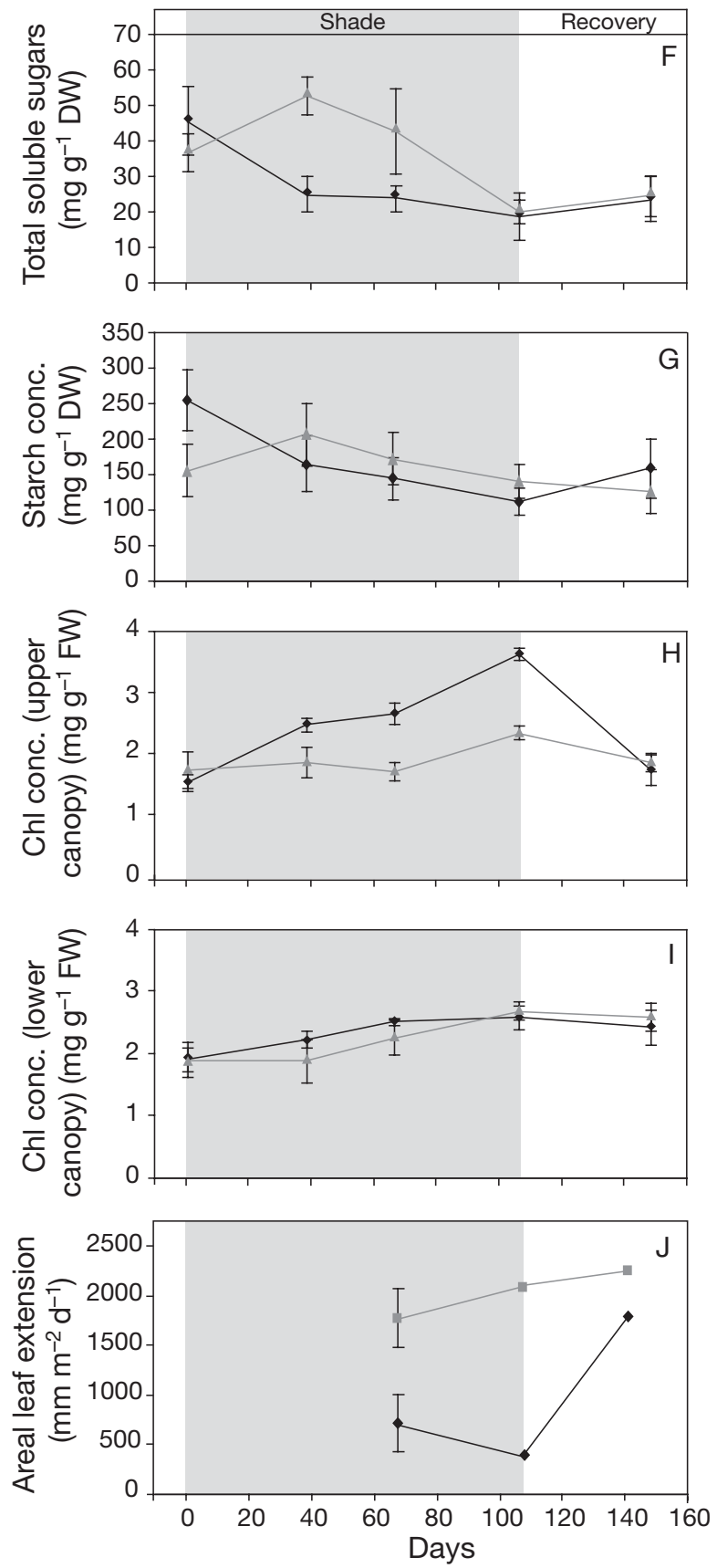

Fig. 4. Amphibolis griffithii. Physiological characteristics of plants during shading and recovery periods in shaded and control plots: (A) rhizome soluble sugars, (B) rhizome starch, (C) chl $a / b$ in upper canopy leaves, (D) chl $a / b$ in lower canopy leaves, (E) leaf extension rates, $(\mathrm{F})$ leaf soluble sugars, $(\mathrm{G})$ leaf starch, $(\mathrm{H}) \mathrm{chl} a+b$ in upper canopy leaves, (I) chl $a+b$ in lower canopy ${ }^{*}$ leaves, and $(\mathrm{J})$ areal leaf extension rates. Data are means $( \pm \mathrm{SE}, \mathrm{n}=4)$. DW: dry weight; FW: fresh weight 
The marked response in the total chlorophyll concentrations in leaves, albeit limited to the upper canopy, has been noted in other seagrasses, such as Thalassia testudinum (Lee \& Dunton 1997), Halodule pinifolia and Halophila ovalis (Longstaff \& Dennison 1999). Presumably, this indicates a physiological response to maximise energy-harvesting efficiency under reduced PPFDs, as noted for other species (Carruthers 1999). The absence of any chlorophyll response in lower canopy leaves may reflect the preadaptation of those leaves to canopy self-shading and be analogous to the vertical differences in pigment concentrations along the leaves of seagrasses with strap-like leaf morphologies. Alternatively, plants may be allocating precious resources to those leaves in the least light-limited conditions, at the top of the canopy.

The loss of algal biomass under shade conditions was not due simply to the loss of substrate, since the decline was still apparent when normalised to leaf biomass. The rapid loss of macroalgae in shaded conditions may reflect their limited storage reserves and associated capacity to withstand shading. If the loss of epiphytes was due to light limitation, it has potentially important trophic implications, since epiphytic algae are an important food source for a range of vertebrate and invertebrate grazers (Nielsen \& Lethbridge 1989).

A wide range of morphological and physiological variables responded to reduced light availability within a 1 mo period; these variables may be useful as sub-lethal indicators of light-reduction stress in Amphibolis spp. ecosystems. To be useful, sub-lethal indicators should respond rapidly and prior to the actual loss of seagrass, and be responsive, solely or predominantly, to the environmental stress in question. In these respects, the loss of epiphytic algae and changes in the pigment and carbohydrate content of leaves and the extension rate of leaves all show promise as sub-lethal indicators. Some of these variables are known to respond to light reduction in other seagrass ecosystems (Lee \& Dunton 1997, Longstaff \& Dennison 1999) and, conceptually, can be explained in terms of light reduction. Developing practical indicators from the responses will require characterising the responses under different intensities and durations of shading and inclusion of any confounding effects of other environmental factors.

\section{Recovery}

The majority of variables that responded to light reductions showed substantial recovery within 42 d. The reductions in canopy self-shading allowed increased light to penetrate throughout the canopy, and this, together with the changes in pigment concentra- tions of the remaining leaves, probably provides the capacity for the apparently rapid recovery. The extent and rate of recovery in these variables indicates that Amphibolis griffithii is largely able to withstand a single episode of high-intensity PAR reduction over 3 mo. This contrasts Posidonia sinuosa, another large, meadow-forming species in the region, which showed a low degree of recovery 9 mo after removal of $99 \%$ shading (Gordon et al. 1994). This may reflect a fundamental difference between species in such genera as Amphibolis and Posidonia and supports Walker et al.'s (1999) separation of the genera in their functional-form model based on growth rates and responsiveness to perturbation.

In concluding that Amphibolis griffithii can withstand short-term, intense reductions in the availability of light, it is important to note 3 caveats. First, the study coincided with the period of peak carbohydrate stores in A. griffithii (Carruthers \& Walker 1997) and, potentially, the greatest capacity for the plants to withstand shading by drawing on those reserves. Reductions in light at other times of the year may generate more severe impacts or reduced capacity to recover. Second, rhizome starch concentrations showed a relatively low degree of recovery following removal of shading, suggesting that $A$. griffithii may be less able to withstand repetitive shading events without intervening periods during which storage reserves can be re-established. Finally, in these experiments, the shoots under the shade treatments were not isolated from the surrounding, unshaded meadow, offering the possibility for translocation of reserves from unshaded meadow into the shaded shoots. If this was occurring, then impacts could be more severe if a regional shading event occurred, since adjacent, unaffected meadow would not be available.

Acknowledgements. We thank Dr. K. McMahon for her helpful review of the manuscript. This research was funded by the Western Australian Government's Strategic Research Fund for the Marine Environment.

\section{LITERATURE CITED}

Bulthius DA (1983) Effects of in situ light reduction on density and growth of the seagrass Heterozostera tasmanica (Martens ex Aschers.) den Hartog in Western Port, Victoria, Australia. J Exp Mar Biol Ecol 67:91-103

Carruthers TJB (1999) Within canopy growth strategies of the two seagrass species Amphibolis griffithii (J. Black) den Hartog and Amphibolis antarctica (Labillardiere) Sonder \& Ascherson ex Asherson. In: Walker DI, Wells FE (eds) The seagrass flora and fauna of Rottnest Island, Western Australia. Western Australian Museum, Perth

Carruthers TJB, Walker DI (1997) Light climate and energy flow in the seagrass canopy of Amphibolis griffithii (J. M. Black) den Hartog. Oecologia 109:335-341 
Carruthers TJB, Longstaff B, Dennison W, Abal E, Aioi K (2001) Measurement of light penetration in relation to seagrass. In: Short FT, Coles RG (eds) Global seagrass research methods. Elsevier Science BV, Amsterdam

Collier CJ (2006) Characterising responses of the seagrass Posidonia sinuosa to changes in light availability. $\mathrm{PhD}$ dissertation, Edith Cowan University, Perth

Czerny AB, Dunton KH (1995) The effects of in situ light reduction on the growth of two subtropical seagrasses Thalassia testudinum and Halodule wrightii. Estuaries 18:418-427

Duarte CM (2002) The future of seagrass meadows. Environ Conserv 29:192-206

Duarte CM, Kirkman H (2001) Methods for the measurement of seagrass abundance and depth distribution. In: Short FT, Coles RG (eds) Global seagrass research methods. Elsevier Science BV, Amsterdam

Dubois M, Gilles KA (1956) Colorimetric method for the determination of sugars and related substances. Anal Chem 28: 350-356

Ducker SC, Foord JN, Knox BR (1977) Biology of Australian seagrasses: the genus Amphibolis C. Agardh (Cymodoceaceae). Aust J Bot 25:67-95

Escudero A, del Arco JM, Sanz IC, Ayala J (1992) Effects of leaf longevity and retranslocation efficiency on the retention time of nutrients in the leaf biomass of different woody species. Oecologia 90:80-87

Fowler J, Cohen L (1990) Practical statistics for field biology. Wiley, Chichester

Gordon DM, Grey KA, Chase SC, Simpson CJ (1994) Changes to the structure and productivity of a Posidonia sinuosa meadow during and after imposed shading. Aquat Bot 47:265-275

Granger S, Lizumi H (2001) Water quality measurement methods for seagrass habitat. In: Short FT, Coles RG (eds) Global seagrass research methods. Elsevier Science BV, Amsterdam

Hemminga MA, Duarte CM (2000) Seagrass ecology. Cambridge University Press, Cambridge

Lee KS, Dunton H (1997) Effects of in situ light reduction on the maintenance, growth and partitioning of carbon resources in Thalassia testudinum Banks ex Konig. J Exp Mar Biol Ecol 210:53-73

Longstaff BJ, Dennison WC (1999) Seagrass survival during pulsed turbidity events: the effects of light deprivation on the seagrasses Halodule pinifolia and Halophila ovalis. Aquat Bot 65:105-121

Marbà N, Walker DI (1999) Growth, flowering, and popula-

Editorial responsibility: Otto Kinne (Editor-in-Chief), Oldendorf/Luhe, Germany tion dynamics of temperate Western Australian seagrasses. Mar Ecol Prog Ser 184:105-118

Masini RJ, Cary JL, Simpson CJ, McComb AJ (1995) Effects of light and temperature on the photosynthesis of temperate meadow-forming seagrasses in Western Australia. Aquat Bot 49:239-254

Nielsen J, Lethbridge R (1989) Feeding and the epiphyte food resource of gastropods living on the leaves of the seagrass Amphibolis griffithii in southwestern Australia. J Malacol Soc Aust 10:47-58

Paling EI, McComb AJ (1994) Nitrogen and phosphorus uptake in seedlings of the seagrass Amphibolis antarctica in Western Australia. Hydrobiologia 294:1-4

Paling EI, McComb AJ (2000) Autumn biomass, belowground productivity, rhizome growth at bed edge and nitrogen content in seagrasses from Western Australia. Aquat Bot 67:207-219

Peralta G, Perez-Llorens J, Hernandez I, Vergara J (2002) Effects of light availability on growth, architecture and nutrient content of the seagrass Zostera noltii Hornem. J Exp Mar Biol Ecol 269:9-26

Peralta G, Brun FG, Hernandez I, Vergara JJ, Perez-Llorens JL (2005) Morphometric variations as acclimation mechanisms in Zostera noltii beds. Estuar Coast Shelf Sci 64: 347-356

Quarmby C, Allen SE (1989) Organic constituents. In: Allen $\mathrm{SE}$ (ed) Chemical analysis of ecological materials. Blackwell Scientific, Oxford

Ruiz JM, Romero J (2003) Effects of disturbances caused by coastal constructions on spatial structure, growth dynamics and photosynthesis of the seagrass Posidonia oceanica. Mar Pollut Bull 46:1523-1533

Short FT, Duarte C (2001) Methods for the measurement of seagrass growth and production. In: Short FT, Coles RG (eds) Global seagrass research methods. Elsevier Science $\mathrm{BV}$, Amsterdam

Stapel J, Hemminga MA (1997) Nutrient resorption from seagrass leaves. Mar Biol 128:197-206

Touchette BW, Burkholder JM (2000) Overview of the physiological ecology of carbon metabolism in seagrasses. J Exp Mar Biol Ecol 250:169-205

Walker DI, McComb AJ (1992) Seagrass degradation in Australian coastal waters. Mar Pollut Bull 25:191-195

Walker D, Dennison W, Edgar G (1999) Status of Australian seagrass knowledge. In: Butler A, Jernakoff P (eds) Seagrass in Australia: strategic review and development of an R \& D plan. CSIRO Publishing, Collingwood, p 1-24

Submitted: March 7, 2006; Accepted: December 22, 2006 Proofs received from author(s): June 28, 2007 